\title{
Hubungan antara pelecehan seksual dengan kepuasan kerja dan tekanan kerja pada karyawan wanita di tiga universitas negeri kawasan Lembah Klang, Malaysia
}

\author{
Fonny Dameaty Hutagalung*
}

Arifin $\mathrm{Hj}$ Zainal

\author{
Universitas Kebangsaan \\ Malaysia-Bangi Selangor
}

\begin{abstract}
ABSTRAK
Penelitian ini bertujuan untuk mengetahui hubungan pelecehan seksual dengan kepuasan kerja dan tekanan kerja pada karyawan wanita di tiga universitas negeri kawasan Lembah Klang, Malaysia. Selain itu, kami juga meneliti perbedaan pelecehan seksual berdasarkan perbedaan kategori umur pekerja serta interaksi antara pelecehan seksual dan umur terhadap kepuasan kerja dan tekanan kerja. Dalam meneliti, kami menggunakan satu set angket yang mengukur pelecehan seksual, kepuasan kerja, tekanan kerja dan demografi partisipan. Jumlah partisipan adalah sebanyak 1423 orang yang direkruit dengan teknik pengambilan purposive random sampling dan rambang. Hasil menunjukkan keseluruhan pelecehan seksual terjadi pada level sedang sebanyak 53\%, ada hubungan negatif signifikan antara pelecehan seksual dengan kepuasan kerja dan ada hubungan positif signifikan antara pelecehan seksual dengan tekanan kerja. Hasil juga menunjukkan ketiadaan interaksi antara pelecehan seksual dan umur terhadap kepuasan kerja dan tekanan kerja.
\end{abstract}

Kata kunci: Pelecehan seksual, kepuasan kerja, tekanan kerja

\section{The relationship of sexual harassment with job satisfaction and job stress among female employee at three national universities in Lembah Klang, Malaysia}

\begin{abstract}
The present study was aimed to examine the relationships of sexual harassment on job satisfaction and job stress among female employees at three universities in Lembah Klang, Malaysia. In addition, we also examine the sexual harassment differences basing on the employees' age category, as well as the interaction between sexual harassment and age on job satisfaction and job stress. In conducting our research, we used a set of questionnaire measuring sexual harassment, job satisfaction, job stress, and participants' demography. Participants were 1423 people recruited through purposive random sampling and simple random sampling. The results showed that $53 \%$ participants had experience moderate sexual harassment; there was a significant negative correlation between sexual harassment with job satisfaction and a significant positive correlation between sexual harassment with job stress. The results also showed no interaction between sexual harassment and participants' age on job satisfaction and job stress.
\end{abstract}

Keywords: Sexual harassment, job satisfaction, job stress

\footnotetext{
* Korespondensi mengenai penelitian ini dapat dilayangkan kepada Fonny Dameaty Hutagalung melalui e-mail: fdameaty@yahoo.com.my
} 
Pelecehan seksual di tempat kerja merupakan satu pengalaman yang amat mengerikan dan menyiksa perasaan yang menjadi korban. Korban pelecehan seksual akan menghadapi perasaan tertekan, benci, marah, rasa cemas, gelisah, sedih, terhina, sehingga mengganggu emosi, psikologis, kesehatan fisik mereka. Namun, banyak kasus pelecehan seksual yang tidak dilaporkan karena ketakutan korban atas keselamatan dirinya, kesulitan ekonomi (e.g., takut diturunkan pangkat), dipecat, dihina dan sebagainya (Bullogh 1991; Hamilton, Alagna, King \& Loyd, 1987).

Pelecehan seksual merupakan diskriminasi berdasarkan gender yang melibatkan perilaku seksual yang tidak diinginkan oleh korban wanita di tempat kerja (Brewer dan Berk, 1982). Suatu sumber mengatakan bahwa pemikiran tradisional yang mendiskriminasikan serta ketidakpercayaan pada kemampuan wanita menjadi penghalang utama wanita di dunia kerja (Berita Harian, 17 September 2000). Selain itu, dikatakan bahwa pelecehan seksual di tempat kerja timbul dari hubungan kerja harian yang melibatkan sikap individu di dalam suatu organisasi dan melibatkan golongan pria dan wanita (Abdul Rahim, 2003).

Walaupun pelecehan seksual dapat terjadi pada pria maupun wanita, lebih banyak pekerja wanita yang menjadi korban pelecehan seksual dibanding pekerja pria. Selanjutnya, ada tendensi yang jelas jika semakin banyak pekerja pria di suatu tempat kerja, gejala pelecehan seksual terhadap wanita di tempat kerja tersebut meningkat (Gutek, 1985; Terpstra dan Cook, 1985; Gutek dan Larwood, 1985; Gibss, 1991). Kasus-kasus pelecehan seksual pekerja wanita dikatakan meningkat jumlahnya. Berdasarkan penelitian-penelitian terdahulu sekitar 40\% hingga $70 \%$ korban pelecehan seksual adalah wanita (Silverman, 1996; Renzetti dan Curan, 1999; Beauvais, 2003; Fain dan Anderton, 2005; Persekutuan Majikan Malaysia, 2009).

Ancaman pelecehan seksual yang dialami oleh kaum wanita di tempat kerja, baik berbentuk fisik maupun emosi merupakan masalah yang serius pada saat ini (U.S. Merit System Protection Board, 2004; Fitzgerald dan Shullman, 2003). Kenyataan ini disokong oleh Singer (2003) bahwa pelecehan seksual merupakan masalah kritikal yang dihadapi wanita, karena berkaitan dengan pelanggaran hak asasi, bersifat kriminal dan diskriminatif. Di Amerika, dalam tempo dua tahun saja lebih kurang 12.000 orang pekerja wanita adalah korban perkosaan atau adanya unsur ingin memperkosa oleh supervisor dan rekan kerja mereka. Sedangkan di Malaysia jumlah kasus perkosaan dan pelecehan dinilai tinggi yaitu 3906 dari tahun 2005 hingga 2008 yang diakibatkan oleh keganasan dan pelecehan seksual di tempat kerja. Pada masa ini, hukuman yang dikenakan terhadap pesalah tergantung kepada pertimbangan atasan di tempat kerja, yaitu mau menggantung atau memecat pekerja tersebut. Oleh sebab itu diperlukan hukuman yang jelas untuk pelaku pelecehan seksual di tempat kerja (Noriah Kasnon, 2010).

Penelitian mengenai pelecehan seksual di tempat kerja sudah sering dilakukan, namun begitu, penelitian berskala besar mengenai pelecehan seksual di universitas negeri Malaysia masih sangat sedikit, kebanyakan kajian dijalankan di perusahaan-perusahaan swasta, pabrik-pabrik atau organisasi-organisasi tertentu (Ishak dan Lai Lee Ching 2001; Sabitha 2002; Yahaya dan Zulaiha 2002; Arifin dan Mimi Azlina 2003; Hishamudin et al., 2003; Ahmad Syukran 2004; Ishak et al., 2004; Rohani 2005; Mohd Nazri Ismail et al., 2007; BERNAMA 2009). Meskipun telah terdapat beberapa penelitian pelecehan seksual yang dijalankan di universitas negara ini seperti penelitian Badriyah (1988) dan Sabitha, (2003), namun secara ringkasnya masih sangat sedikit dan belum banyak yang mampu melaporkan pelecehan seksual yang terjadi pada pekerja wanita di universitas negeri Malaysia.

Selanjutnya bentuk-bentuk gangguan paling sering terjadi di tempat kerja adalah pelecehan seksual secara lisan yaitu sebanyak 60\% dan fisik sebanyak 50\% (European Commission, 1999). Setengah kasus-kasus pelecehan seksual ini sukar ditangani karena 
dilakukan oleh pria yang mempunyai kedudukan dan pengaruh di tempat kerja. Mengikuti laporan ILO (International Labour Office, 2001), 92\% pelecehan seksual di tempat kerja di lakukan oleh golongan atasan atau pimpinan pria dan belum banyak wanita yang melapor. Mereka hanya saling berbagi pengalaman dan kemarahan sesama mereka saja. Sebagian dari mereka telah mula mempersoalkan perhatian dari pimpinan atau atasan mereka adalah satu keuntungan atau kerugian kepada mereka. Oleh karena itu penulis merasa adanya keperluan untuk melakukan penelitian mengenai pelecehan seksual yang terjadi di tiga universitas negeri terbesar di Malaysia.

Menurut Gutek (2006) ada pengaruh pelecehan seksual dengan karakterteristik korban antara lainnya adalah umur korban. Hasil penelitian lalu menunjukkan golongan pekerja yang lebih banyak dilecehkan adalah mereka yang terdiri dari golongan wanita berumur muda, janda, dan wanita tidak kawin (Sabitha 2003; $\mathrm{Ng}$ et al., 2002).

Pelecehan seksual adalah istilah yang diambil dari kata sexual harassment. Menurut EEOC (2002) pelecehan seksual merupakan perilaku yang non-resiprokal (tak terbalaskan) dari pria yang menurut peran jenis wanita di luar batas fungsinya sebagai orang yang bekerja. Bentuk perilakunya sangat beraneka ragam, dapat berupa rayuan, komentar yang bernada seksual, sentuhan di bagian tubuh tertentu pada pekerja wanita yang menjadi sasaran, permintaan melakukan hubungan seksual dan ajakan kencan.

Berdasarkan kasus-kasus pelecehan seksual yang dilaporkan di negara ini terdapat kasus-kasus pengadilan perindustrian yang mendapat perhatian masyarakat Malaysia seperti kasus PT. Jenicco lwn Lillian de Costa, Perusahaan Melawar lwn Abu Osman, PT. Projek Lebuhraya Utara Selatan Bhd. lwn Azahar Ahmad, PT. Edaran Communication lwn Tahar Mohamad (dalam Ahmad Syamsul, 2005). Juga terdapat kasus-kasus yang dilaporkan media massa seperti lima orang karyawan wanita di pabrik cip komputer menjadi korban pelecehan seksual di tempat kerja yang dilakukan oleh atasannya (Utusan Malaysia, 29 Maret 1999), beberapa karyawan wanita di sebuah hotel terkenal di Pulau Pinang menyatakan mereka mengalami pelecehan seksual yang dilakukan manajer hotel (Harian Metro, 27 Februari 2000), kasus Rubiyah Togi, yaitu seorang operator mesin menyatakan menerima pelecehan seksual secara lisan dan fisik oleh dua orang atasannya (Utusan Malaysia, 29 Mach 2001).

Pelecehan seksual di universitas juga dilaporkan terjadi pada sesama tenaga pengajar atau staf di universitas seperti seorang dosen wanita di universitas negeri di Selangor yang membuat laporan kepada pihak berwajib polisi bahwa dia telah dilecehkan secara seksual oleh seorang dekan sebuah fakultas di universitas tersebut. Sumber-sumber lain juga menyebutkan pelaku pernah melakukan perbuatan yang sama terhadap dosen lain namun tidak membuat laporan. Akhirnya kasus ini berakhir begitu saja tanpa ada pembelaan karena kurang bukti untuk menyeretnya ke muka pengadilan (Harian Metro, 22 Oktober 2000).

Sesuai dengan sifatnya yang tidak diharapkan, pelecehan seksual berdampak negatif yang beraneka ragam. $\mathrm{Ng}$ et al. (2003) menyatakan dampak negatif akibat pelecehan seksual di tempat kerja dapat mempengaruhi motivasi, produktivitas, kepuasan kerja, peningkatan tekanan, rasa rendah diri, karir terhambat, dikucilkan oleh kawan-kawan di tempat kerja, dan lebih parah lagi dapat merusakkan karir pekerja wanita yang menjadi korban bahkan bisa menyebabkan pekerja wanita dipecat atau diberhentikan bekerja.

Data menunjukkan bahwa lebih dari $10 \%$ wanita berhenti bekerja sebagai akibat dari adanya pelecehan seksual di lingkungan kerja. Akibat lainnya adalah dampak psikis korban seperti mudah marah, perasaan terasing, kesepian, tidak berdaya, merasa bersalah, kurang percaya diri, perasaan ketakutan, merusakkan kehidupan pribadi, dan putus asa (Gutek, 2003).

Dari uraian di atas mengeni pelecehan seksual dan permasalahannya maka tujuan penelitian ini adalah: 
1. Mengetahui tahap pelecehan seksual yang terjadi di tiga universitas negeri kawasan Lembah Klang, Malaysia.

2. Mengetahui adakah hubungan pelecehan seksual dengan kepuasan kerja dan tekanan kerja.

3. Mengetahui adakah perbedaan pelecehan seksual yang terjadi kepada pekerja dengan tiga tahap umur berbeda .

4. Mengetahui adakah kesan interaksi pelecehan seksual dan umur terhadap kepuasan kerja dan tekanan kerja.

Berdasarkan penjelasan dan kenyataan di atas penulis perlu melakukan pengujian, maka hipotesis penelitian ini adalah:

1. Tahap pelecehan seksual di tiga universitas negeri di kawasan Lembah Klang adalah rendah.

2. Ada hubungan antara pelecehan seksual dengan kepuasan kerja, yaitu dengan semakin sering pelecahan seksual terjadi maka akan dapat menurunkan kepuasan kerja karyawan.

3. Ada hubungan antara pelecehan seksual dengan tekanan kerja, yaitu dengan semakin sering pelecehan seksual terjadi maka akan dapat meningkatkan tekanan kerja karyawan.

4. Pekerja wanita berusia 26 hingga 50 tahun akan lebih rentan dari pekerja berusia 50 tahun ke atas dalam mengalami pelecehan seksual.

5. Ada interaksi antara pelecehan seksual dan umur terhadap kepuasan kerja.

6. Ada interaksi antara pelecehan seksual dan umur terhadap tekanan kerja.

\section{METODE}

\section{Partisipan}

Penelitian ini dilakukan dengan cara memberikan satu set angket kepada karyawan. Sebanyak 1423 orang karyawan wanita dari tiga universitas negeri kawasan Lembah Klang, Malaysia berpartisipasi dalam penelitian ini. Kami menggunakan dua teknik pengambilan sampel, yaitu purposive random sampling dan rambang. Kajian dijalankan di tiga universitas negeri di Malaysia, yaitu Universitas Kebangsaan Malaysia (UKM), Universitas Putra Malaysia (UPM), dan Universitas Teknologi MARA (UiTM). Untuk partisipan penelitian di UKM dan UPM teknik pengambilan sampel yang digunakan adalah purposive random sampling, sedangkan di UiTM menggunakan teknik purposive random sampling dan rambang, hal ini disebabkan terdapat kesukaran mendapat perizinan untuk menjalankan kajian di tiga fakultas yang telah dipilih dengan menggantikan fakultas atau bahagian lain sebagai subjek kajian di universitas tersebut dengan menggunakan teknik secara rambang.

\section{Alat ukur}

Dalam penelitian ini alat ukur yang digunakan adalah alat ukur yang telah standar dan telah banyak diuji validitas dan reliabilitasnya. Pelecehan seksual diukur menggunakan alat pengukuran Sex and Workplace yang dibuat oleh Gutek (1985, 8 aitem; 1 = tidak pernah, 2 = tidak pasti, $3=y a$ pernah $; \alpha=.816 ;$ corrected item-to-total correlation $=0.455$ sampai 0.812). Aitem dibuat berdasarkan dua bentuk gangguan, yaitu gangguan secara lisan dan fisik. Sistem penilaian alat pengukuran pelecehan seksual dengan menjumlahkan jawaban yang telah ditandakan oleh subjek. Nilai atau skor terendah yang diperolehi oleh subjek adalah $8(1 \times 8)$ dan skor maksimal ialah $24(3 \times 8)$. Bagi tujuan statistik deskriptif, tahap pelecehan seksual dibagi kepada tiga tahap yaitu rendah (skor 8 hingga 13), menengah (14 hingga 19) dan tinggi (20 hingga 24). Kepuasan kerja diukur dengan menggunakan alat pengukuran Occupational Stress Indicator (OSI) yang dibuat Cooper, Sloan, dan Williams $(1988,1=$ sangat tidak memuaskan $-6=$ sangat memuaskan; $\alpha=.97 ;$ corrected item-to-total correlation = .57 sampai .95). Tekanan kerja diukur dengan Job Stress Survey dari Charles D. Spielberger dan Peter R. Vagg (1992, 30 aitem; 1 = tidak tertekan -9 = tertekan; $\alpha=.97$; 
corrected item-to-total correlation $=.47$ sampai .85$)$. Faktor demografik yang diukur pada kajian ini adalah umur pekerja wanita. Umur dibagi kepada tiga kategori umur yaitu umur 25 tahun ke bawah, 26 hingga 50 tahun dan 50 tahun ke atas.

\section{HASIL}

Secara garis besar hasil penelitian ini dapat dijelaskan sebagai berikut:

1. Hasil menunjukkan keseluruhan karyawan wanita yang bekerja di universitas negeri kawasan Lembah Klang, Malaysia mengalami pelecehan seksual baik secara lisan dan fisik pada pada tahap tinggi sebanyak $26 \%(N=368)$, tahap cukup (moderate) sebanyak $53 \%(N=750)$ dan pada tahap rendah sebanyak $21 \%(N=305)$. Tahap pelecehan seksual paling banyak pada tahap cukup 53\%. Dengan demikian dapat dikatakan bahwa hipotesis yang diajukan dalam penelitian ditolak yang menyatakan tahap pelecehan seksual karyawan wanita pada tiga universitas di tahap rendah.

2. Matriks interkorelasi menunjukkan bahwa ada hubungan negatif signifikan antara pelecehan seksual terhadap kepuasan kerja pada karyawan wanita pada tiga universitas negeri kawasan Lembah Klang di Malaysia, $r=-.57, p<.05$. Dengan demikian dapat dikatakan bahwa hipotesis yang diajukan dalam penelitian diterima yang menyatakan ada hubungan antara pelecehan seksual terhadap kepuasan kerja.

3. Matriks Interkorelasi menunjukkan adanya hubungan positif signifikan antara pelecehan seksual terhadap tekanan kerja pada karyawan wanita pada tiga universitas negeri kawasan Lembah Klang, Malaysia, $r=.65, p<.05$. Dengan demikian dapat dikatakan bahawa hipotesis yang diajukan dalam penelitian yang menyatakan ada hubungan antara pelecehan seksual terhadap tekanan kerja yang dihasilkan diterima.

4. Keputusan inferensial ujian statistik One-Way ANOVA menunjukkan ada perbedaan yang signifikan antara pelecehan seksual dengan tahap umur yang berbeda, $F(2,1420)=$ $3.210, p<.05$. Berdasarkan ujian Post Hoc, perbedaan nilai min karyawan wanita berumur 26 hingga 50 mendapati paling tinggi mengalami pelecahan seksual $(M=$ 13.172) dan paling rendah adalah karyawan wanita 51 tahun ke atas $(M=11.791)$. Dengan demikian dapat dikatakan bahawa hipotesis yang diajukan dalam penelitian diterima yang menyatakan karyawan berumur 26 hingga 50 lebih dari umur 50 tahun ke atas lebih rentan mengalami pelecehan seksual.

5. Keputusan inferensial ujian statistik Two Way ANOVA menunjukkan bahwa tiada kesan interaksi yang signifikan antara pelecehan seksual dan umur terhadap kepuasan kerja, $F(2,1414)=1.957$, n.s. Berarti hasil analisis. Dengan demikian dapat dikatakan bahawa hipotesis yang diajukan dalam penelitian ditolak yang menyatakan terdapat interaksi yang signifikan antara pelecehan seksual dan umur terhadap kepuasan kerja.

6. Keputusan inferensial ujian statistik Two Way NOVA menunjukkan tiada kesan interaksi yang signifikan antara pelecehan seksual dan umur terhadap tekanan kerja, $F(2,1414)=$ 1.382 , n.s. Dengan demikian dapat dikatakan bahawa hipotesis yang menyatakan terdapat interaksi yang signifikan antara pelecehan seksual dan umur terhadap tekanan kerja ditolak.

\section{DISKUSI}

Hasil penelitian ini menunjukkan penolakan Hipotesis 1 yang menyatakan tahap pelecehan seksual yang dialami pekerja wanita di tiga universitas negeri kawasan Lembah Klang Malaysia adalah tahap rendah karena hasil penelitian ini, menunjukkan tahap pelecehan seksual adalah tahap cukup sebanyak 53\% dan tahap tinggi pula sebanyak $26 \%$. Secara keseluruhan keputusan penelitian ini menunjukkan telah banyak karyawan wanita sering dilecehkan secara seksual di tempat kerja. Hal ini seharusnya tidak boleh terjadi karena universitas adalah satu tempat individu untuk menuntut ilmu pengetahuan dan 
seharusnya menjadi contoh yang baik sebagai tempat kerja yang selamat namun ternyata juga tidak selamat karena tidak bebas dari pelecehan seksual. Selanjutnya dengan hasil penelitian ini dapat memberi penilaian yang kurang baik terhadap nama baik universitas terlebih lagi penilaian orang luar terhadap universitas (Sabitha, 2003).

Keadaan ini terjadi mungkin disebabkan oleh beberapa faktor seperti terdapat masalah gender yang tidak seimbang di tempat kerja. Jumlah pekerja wanita yang semakin banyak dibanding lelaki bisa mewujudkan suasana dan keadaan yang mendorong terjadinya pelecehan seksual. Di Malaysia majoritas yang bekerja di universitas adalah wanita namun atasan adalah kaum lelaki. Wanita adalah golongan bawahan yang harus tunduk dan patuh di bawah kuasa kaum lelaki. Kuasa yang ada pada kaum lelaki ini dapat disalah-gunakan untuk memaksa mereka yang mempunyai status yang lebih rendah (pekerja wanita) dan ini juga dapat menghambat kaum wanita untuk mendapatkan kedudukan yang lebih tinggi (Statistik Kementrian Tenaga Kerja Malaysia, 2005). Akibatnya pekerja wanita yang menjadi pilihan dianggap sebagai objek seks yang menarik dalam perhubungan antara rekan sekerja dan atasan lelaki di tempat kerja (Sabitha, 2002; Abdul Rahim 2003).

Selanjutnya dari sudut biologi, pria dan wanita adalah berbeda, yaitu lelaki mempunyai keadaan fisik yang lebih kuat dan lebih mudah mengalahkan dan memperalat wanita. Di mana kaum pria mempunyai kepribadian dan karakter yang secara natural lebih agresif dan dominan menyebabkan mereka merasa lebih berkuasa dari segi seksual. Sedangkan wanita mempunyai kepribadian dan karakter seorang yang peramah, bergaya, dan lemah lembut (Fiske dan Stevens, 1993; Prentice dan Carvanza, 2002). Akibat perbedaan ini menyebabkan banyak wanita telah mengalami pelecehan seksual. Kaum pria tahu bahwa wanita secara fisik memiliki kelemahan, wanita lebih suka mengalah dan tidak berani menentang keganasan kaum pria. Kelemahan ini dijadikan senjata oleh kaum pria untuk mengganggu pekerja wanita (Lengnick-Hall, 1995; Tangri \& Hayes, 1997; Welsh, 1999).

Keputusan penelitian ini hampir sama dengan beberapa keputusan penelitian terdahulu seperti yang diperolehi oleh Brooks dan Perot (1991), Fitzgerald et.al (1999), Cummings (2005), dan Barak (1999), yaitu pekerja wanita mengalami pelecehan seksual pada tahap cukup atau sedang (moderate). Selanjutnya, juga terdapat kajian pelecehan seksual dalam kalangan pelajar dengan dosen atau profesor. Penelitian sebelumnya sehubungan dengan gangguan seksual di institusi pendidikan telah dilakukan oleh cendikiawan barat seperti Pope, Levinson dan Schaver (2001), Benson dan Thomson (2003), Cammaert (2004), McKinney et.al.(2004) telah menunjukkan masalah pelecehan seksual antara golongan tenaga pengajar dengan pelajar. Juga terdapat keputusan memeranjatkan dari penelitian Rubin dan Rogers (2004), yaitu sebanyak $70 \%$ pelajar wanita mengalami pelecehan seksual dalam situasi pembelajaran di universitas.

Hasil penelitian berikutnya menunjukkan penerimaan Hipotesis 2 yang menyatakan terdapat hubungan yang signifikan antara pelecehan seksual dengan kepuasan kerja tetapi bersifat negatif. Ini bermakna semakin sering pekerja wanita menjadi korban pelecehan seksual, maka semakin rendah kepuasan kerjanya. Keputusan penelitian seperti penelitian U.S. Merit Sistem Protection Board (2004) yang menunjukkan hasil yang hampir sama yaitu sebanyak $55 \%$ korban pelecehan seksual dilaporkan adanya perasaan tidak menyenangkan terhadap pekerjaan, kepuasan kerja menurun dan keadaan emosi serta fisik juga turut terganggu. Akibatnya korban pelecehan seksual ini tiada semangat untuk berkembang dan memajukan diri di dalam pekerjaan. Penelitian ini membuktikan bahwa pelecahan seksual harus ditindak-lanjuti di tempat kerja, apalagi di universitas karena tiada nilai positif yang didapat dari pelecehan seksual. Pelecehan seksual hanya memberi kesan negatif kepada kepuasan kerja korban dan boleh mempengaruhi prestasi kerja mereka. Jika keadaan ini dibiarkan, maka akan berdampak buruk pada nama baik universitas tersebut. Dengan 
demikian dapat disimpulkan, hasil penelitian ini menunjukkan jika pekerja wanita mengalami pelecehan seksual akan memberi pengaruh negatif terhadap pekerjaannya.

Keputusan penelitian menerima Hipotesis 3 yang menyatakan terdapat hubungan positif yang signifikan antara pengalaman gangguan seksual dengan tekanan kerja. Ini berarti pekerja wanita sekiranya mengalami pelecahan seksual di tempat kerja menyebabkan perasaan tertekan baik secara fisik, psikologis, dan emosi. Hasil penelitian ini sama dengan beberapa keputusan penelitian sebelum nya, seperti Yahaya dan Zulaiha (2002), Sabitha (2002) yang menunjukkan bahwa korban pelecehan seksual akan menghadapi berbagai bentuk tekanan dalam bekerja. Ada juga korban yang terpaksa mendapatkan bantuan psikiater atau psikologis untuk meredakan perasaan tertekan.

Hasil penelitian menerima Hipotesis 4, yaitu perkerja wanita berumur 26 sehingga 50 tahun lebih mengalami pelecehan seksual dibanding pekerja berumur 50 tahun ke atas. Berdasarkan keputusan juga menunjukkan tempat ke-dua tertinggi pelecehan gangguan seksual berlaku kepada pekerja berumur di bawah 25 tahun. Menurut Levinson (2003) dalam kedua kategori umur tersebut wanita sedang membina karier, berkeinginan besar untuk mencapai kejayaan dalam hidup dan keluarga, seandainya mereka menjadi korban pelecehan seksual oleh kaum pria di tempat kerja maka bisa mengganggu kariernya dan lebih parah lagi bisa menurunkan kualitas kepuasan hidup si korban. Keputusan penelitian ini didukung penelitian sebelumnya seperti Connell dan Korabi (2000), Yahaya Mahmood dan Zulaika (2002), Utusan Malaysia (2003) dan Rohani (2004) bahwa pekerja wanita yang berusia muda dan pertengahan lebih sering mengalami pelecehan seksual dibanding pekerja wanita yang lebih berumur 51 tahun ke atas. Mereka sering menjadi korban pelecehan seksual daripada kaum pria disebabkan oleh faktor fisik dan psikologis yang ada pada diri mereka.

Hasil penelitian ini telah membuktikan bahawa Teori Biologis daripada Tangri et al (1982) yang menjadi asas teori penelitian ini telah terbukti dan boleh digunakan, yaitu pekerja wanita khususnya berusia muda dan pertengahan mempunyai tarikan seksual yang lebih tinggi dibanding yang telah berusia. Mereka mempunyai penampilan dan sosok tubuh yang lebih menarik dan dapat menarik minat atasan pria terhadap dirinya. Faktor penonjolan seksualitas ini juga bisa mempengaruhi terjadinya pelecehan seksual di tempat kerja karena lelaki mudah terdorong untuk berperilaku seksual yang tidak sehat, termasuk melakukan pelecahan seksual di tempat kerja. Wanita mudah dimanipulasi dan lelaki pula menunjukkan kekuasaannya. Sedangkan dari sudut psikologis pula, pekerja wanita ini mempunyai rasa takut dan malu apabila pelecahan seksual berlaku terhadapnya. Berbeda dengan karakteristik yang dimiliki kaum pria, mereka mempunyai sifat egois yang tinggi dengan adanya sifat takut dan malu yang ada pada wanita maka faktor psikologis itu jugalah yang menyumbang mengapa mereka selalu menjadi sasaran atau korban pelecehan seksual. Yahaya et al. (2002) pula mendapati pekerja wanita berumur lebih dari 35 tahun telah tanggap terhadap pelecehan seksual, sedangkan pekerja wanita yang lebih muda kurang berpengalaman dalam menghadapi pelecehan seksual, Dengan demikian mereka adalah golongan lebih diingini dan menjadi sasaran pria dan sering kali menjadi mangsa gangguan seksual. Selanjutnya dikatakan kaum pria sebagai pelaku pelecehan lebih berani dan mudah mengambil kesempatan atas pekerja wanita berumur muda karena mereka beranggapan bahawa perilaku pelecehan seksual yang dilakukannya tidak akan diambil tindakan hukum sama sekali karena korban masih muda dan takut terhadap proses hukum, takut diberhentikan kerja atau diboikot secara ekonomi.

Keputusan Two-Way ANOVA meramalkan apabila pelecehan seksual berinteraksi dengan faktor umur, namun hasil yang didapatkan tidak memberi kesan interaksi antara pelecehan seksual dengan umur terhadap kepuasan kerja. Hasil ini menunjukkan penolakan Hipotesis 5, yang menyatakan terdapat kesan interaksi yang signifikan antara pelecehan seksual dan umur terhadap kepuasan kerja. Penolakan hipotesis tersebut juga menunjukkan 
min variabel tergantung bagi tiga tahap umur bergerak hampir satu arah di dalam tiga keadaan tahap pelecehan seksual yang berbeda. Keadaan ini menunjukkan faktor umur tidak memberi kesan menaik atau menurun.

Keputusan Two-way ANOVA meramalkan apabila berinteraksi dengan faktor umur tidak mempunyai kesan interaksi yang signifikan atas tekanan kerja. Hasil ini menunjukkan penolakan Hipotesis 6, yang menyatakan terdapat kesan interaksi yang signifikan antara pelecehan seksual dan umur terhadap tekanan kerja. Ini menunjukkan tahap tekanan kerja bagi setiap kategori umur adalah sama di dalam tiga keadaaan tahap pelecehan seksual yang berbeda.

\section{Kesimpulan dan saran}

Pelecehan seksual memberi dampak buruk terhadap korban khususnya wanita. Kajian ini menunjukkan 1118 orang dari 1423 orang pekerja wanita pernah mengalami pelecehan seksual pada tahap cukup (moderate) dan tinggi di tempat kerja dan ini menunjukkan telah banyak pekerja wanita yang bekerja di tiga universitas negeri di Malaysia sering dilecehkan secara seksual dan angka yang ditunjukkan cukup tinggi. Penelitian ini juga membuktikan semakin sering pekerja mengalami pelecehan seksual semakin rendah kepuasan kerja dan semakin tinggi tekanan kerja yang dialami wanita. Mereka yang selalu menerima gangguan adalah golongan pekerja wanita berumur 26 sehingga 50 tahun.

Penelitian ini telah selesai dilaksanakan, pengkaji merasa masih jauh dari sempurna, perlu adanya perbaikan yang menyeluruh. Adapun perbaikan tersebut dapat dilakukan dari sudut metode pelaksanaan penelitian agar keputusan penelitian lebih baik dan mendalam sebagai contoh metode interview dapat disertakan apabila telah terdapat kumpulan fokus subjek yang mengalami gangguan seksual. Sehingga menghasilkan penelitian yang bersifat kuantitas dan berkualitas yang saling melengkapi satu sama lain di dalam mengkaji pelecehan seksual di tempat kerja. Selanjutnya dari sudut partisipan, akan lebih baik jika kajian selanjutnya mengikutkan perspektif lelaki sehubungan dengan pelecehan seksual, sehingga menghasilkan ruang lingkup kajian yang lebih luas dan menyeluruh.

\section{REFERENSI}

Abd. Rahim Abd. Rashid. (2003). Gangguan Seksual-Pengurusan Tingkah Laku dan Perkembangan Gender dalam Organisasi, Kuala Lumpur: Utusan Publication \& Distributors Sdn. Bhd.

Ahmad Shamsul bin Aziz. (2005). Kesalahan Jenayah Gangguan Seksual: Satu Kajian, Disertasi Sarjana muda, Fakulti Undang-Undang, Universiti Kebangsaan MalaysiaBangi.

Anon. (2000). Gangguan seksual khusus di tempat kerja, Harian Metro, 27 Februari: 24

Anon. (2000). Bila kesudahannya gangguan seksual di tempat kerja? Harian Metro, 22 Oktober: 24

Anon. (2001). Gangguan seks tidak mengira status dan pangkat, Utusan Malaysia, 29 Maret: 4.

Andriansson, L. (1993). Ett hogt pris, kartlaggning av sexuella trakasserier vid Gothenborgs universitet. (dlm European Commision, Directorate-General for Employment, Industrial Relations and Social Affairs, Unit V/D.5 Manuscript Completed 1998).

Ahmad Syukran Zainuddin. (2004). Gangguan seksual di tempat kerja : Hubungannya dengan tekanan dan kepuasan kerja serta kecenderungan untuk berhenti kerja. Latihan Ilmiah. Universiti Kebangsaan Malaysia. Bangi. 
Association of Higher Civil Servants. (1993). Equality in the Workplace Report, AHCS Survey, Dublin.

Arifin Hj.Zainal \& Mimi Azlina binti Naim. (2003). Gangguan Seksual dan Hubungannya dengan Kepuasan Kerja dan Prestasi Kerja: Satu Kajian Kes di Sektor Perkilangan. Kertas Kerja, Jabatan Psikologi. Bangi : Universiti Kebangsaan Malaysia.

Badriyah Salleh (1988). Kajian jangka pendek Universiti Sains Malaysia Pulau Pinang 19861988: Kejadian gangguan seksual di dalam kampus USM. Anjuran Persatuan Kakitangan Islam, Universiti Sains Malaysia dan Pusat Islam Universiti Sains Malaysia.

Barak, A. (1999). A cognitive behavioral education workshop to combat sexual harassment in the workplace. Journal Counselling and Development, 72, 595.

Bem. (1974). The measurement of psychological androgyny. Journal of Consulting and Clinical Psychology, 42, 155-162.

Benson, D.J. \& Thomson, G.E. (2003). Sexual harassment on a university campus: The confluence of anchorite relations, sexual interest and gender stratification. Social Problems, 29, 236-251.

BERNAMA. (2009). Kes Gangguan Seksual Di tempat kerja. Kenyataan Timbalan Menteri Sumber Manusia. Terdapat di: www.carigold.com.

Beauvais, K. 2003. Workshop to Combat Sexual Harassment: A Case Study of Changing Attitudes, Signs, 12(1), 130-145

Brewer, M.B. dan R.A. Berk. (1982). Beyond Nine To Five: Introduction. Journal Of Social Issues, 38(4): 1-4.

Brooks, L \& Perot, A.R. Reporting Sexual Harassment. (1991). Psychology of Womwn Quarterly, 15, 31-47.

Bullough, V.L. (1991). “ The Sexually Unusual,” EIDOS, 5(4), 19-20

Cammaert, L.P. (2004). How widespread is sexual harassment on campus? International Jounal of Women's Studies, 8, 388-397.

Charles, S.D. dan Peter, V.R. (1992). Job Stress Survey.

Connel, R.W. (1997). Gender and Power, Stanford, CA: Stnford University press.

Connel, D., \& Korabi, V. (2003). The incidence and impact of women's experiences of sexual harassment in Canadian workplaces. Canadian Review of Sociology and Antrhropology, 4, 541-552.

Cooper, C.L., Sloan S.J. \& Williams, S. (1988). Occupational Stress Indicator: Management guide. Windsor: NFER-Nelson.

Crull,P. (1981). Stress Effects of Sexual harassment on the Job: Implications for Counseling. American Journal of Orthopsychiatric. 52, 539-544.

Cummings. (2005). Academic harassment: sex and denial in scholarly garb. Psychology of Women Quarterly, 12, 329-340

Diekstra, R.F.W., P. de Heus., M.H. Schouten dan .L.D. Houtman. (1994). Werken onder druk: een onderzoek naar omvang en facortoren van werkstress in Nederland. Den Haag. (dlm European Commision, Directorate-General for Employment, Industrial Relations and Social Affairs, Unit V/D.5 Manuscript Completed 1998.

Eagly, A.H. (1987). Sex differences in social behaviour: A social-role analysis. Hillsdale, N.J.: Erlbaum. 
Equal Employment Opportunity Commission. (1998). Guidelines on discrimination on the basis of sex, 29 CFR Part 16040 Federal Register, 45, 219.

EEOC, Coping with recent developments in the law of Sexual harassment, http://www.nss/aw.com/htm., accessed on 10 September 2004.

European Commision. (1999). Sexual Harassment at the workplace in the European Union, Belgium: European Communities.

Einarsen, S., B.I. Raknes, dan S. Berge Matthiesen. (1993). Seksuell trakassering: Bolen og blondinen pa norske arbeidplasser, Bergen. (dlm European Commision, DirectorateGeneral for Employment, Industrial Relations and Social Affairs, Unit V/D.5 Manuscript Completed 1998).

Fain, T.C., \& Anderton, D.L. (2005). Sexual harassment: Organizational Context and Diffuse Status. Sex Roles, 5, 291-311.

Farley, C. (1978). Sexual Shakedown: The Sexual Harassment of Women on the Job. New York: McGraw-Hill Book Company.

Fiske, S.T., dan Stevens, L.E. (1993). What's so special about sex? Gender stereotyping and discrimination. Dalam S. Oskamp dan M. Costanzo (Eds.), Gender issues in contemporary society, 173-196. Newbury Park, CA: Sage.

Fitzgerald, L.F.\& Ormerod, A.J. (1991). Perceptions of sexual harassement: The influence of gender and academic context. Psychology of Women Quarterly, 15, 281-294.

Fitzgerald, L.F., Drasgrow, F., \& Magley, VJ. (1999). Sexual Harrasment in the armed forces: A test of integrated model. Military Psychology, 11, 329-343.

Fitzgerald, L.F., \& Shullman, S.L. (2003). Sexual harassment: A research analysis and agenda for the 1990s. Journal of Vocational Education, 42, 5-27

Franke, K.M. 1997. What's wrong with sexual harassment? Stanford Law Review, 49, 691772.

Gibbs, N. (1991). Office Crime: In a matter of hours, a new vocabulary of laws and risk and expectations entered the language of the factory floor anf the tower suite. Labor Law Journal, 138, 52-54, 63-64. Terdapat di http://www.mith2.umd.edu..

Gutek, B.A. (1985). Sex and Workplace:Impact of sexual behaviour and harassement women, men, and organisation: San Francisco: Jossey-Bass.

Gutek,B., Stromberg, A.H. \& Larwood.L. (1985). Women and work: In Annual Review, Vol.1,2,3. California : Sage Publishing, Inc.

Gutek, B.A., dan Kos, M.P. (2003). Changed women and changed organizations: consequences of and coping with sexual harassment. Journal of Vocational Behavior, 42, $28-48$.

Hamilton, J.A., Alagna, S., King, L., \& Loyd, C. (1987). The emotional consequences of gender-based abuse in the workplace: New Counseling programs for sex discrimination. Women and Therapy, 6, 155-182.

Hatipah, A. (2003). Amalan Murni, Kesedaran Mampu Mencegah Jenayah Rogol, Utusan Malaysia, 10 September: 10.

Hishamuddin Md Som, Lekha Laxman, Maisrah Moh Saa, dan Low Hock Heng. (2003). A Study on sexual harassment in small and medium enterprises of Malaysia. Universiti Teknologi Malaysia. 
Hogbacka, R.I. Kandolin, E. Haavio-Manilla, K. Kauppinen-Toropainen. (1987). Sukupuolinen ahdistelu ja hairinta tyopaikoilla: Suomea koskevia tuloksia. (dlm European Commision, Directorate-General for Employment, Industrial Relations and Social Affairs, Unit V/D.5 Manuscript Completed 1998).

International Labour Office. (2001). "ILO Technical Working Paper: International Perspective on Action Against Sexual Harassment at Work," National Seminar on Action Against Sexual Harassment at Work, 26-28 Jun 2001, Kuala Lumpur.

Ishak Mad Shah dan Lai Lee Ching. (2001). Gangguan seksual di tempat kerja dan hubungannya dengan tekanan kerja dan kepuasan kerja. Jurnal Teknologi, 34, 54-64. Universiti Teknologi Malaysia.

Konrad, M. dan Gutek, B. (1986). Sexual Assault and Other types of sexual harassment by workplace personnel: A Comparison of Antecedents and Consequences, Journal of Occupational Health Psychology, 7, 174-188.

Lengnick-Hall, M.L. (1995). Sexual harassment research: A methodological critique, Personal Psychology, 48, 841-864.

Levinson, J.A. (2003). "Responses to sexual harassment on the job: Legal, organizational and individual actions", Journal of Social Issue, 38, 5-22.

MacKinnon, C.A. (1987). "Difference and Dominance On Sex Discrimination", in; Freeman MDA, 1994, Lloyd's Introduction to Jurisprudence. Ed. ke-6,(1081-1091) London: Sweet and Maxwell Ltd.

MacKinnon. (1995). Sexual harassment: Its First Decade In Court. Dalam B. Price dan N.Sokoloff (Ed.) The Criminal Justice System and Woman (297-311). New York: MacGraw Hill.

Margue, C. (1995). Sexual Harassment, A Day-to-Day Reality at The Workplace in Luxembourg, McKinney, M. 1992. Sexual harassment or working women, Sex Roles, 2, $35-48$.

McKiney, K. dan Maroules N. (2004). Sexual harassment dalam E. Grauerholz dan M.A. Korglewski (eds). Sexual Coercion: A Sourcebook on its Nature, Cause and Prevention . Canada: Lexington Books.

Mohd Nazari Ismail, Lee Kum Chee dan Chan Foong Bee. (2007). Factors influencing sexual harassment in the Malaysia workplace. Asian Academy of Management Journal, 12, 1531.

Ng. C., Zanariah Mohd, Nor \& Maria Chin Abdullah. (2002). A Pioneering Step Sexual Harassment \& The Code of Practice in Malaysia. Kuala Lumpur : Vinlin Press Sdn.Bhd.

Ng. C \& Zanariah Mohd Nor. (2003). Sexual Harassment and code of Practice in Malaysia: A Study of pioneer Companies Implementing the Code, A research report oleh All Women's Action Society and Womens Development Collective, Malaysia.

Noriah Kasnon. (2010). Akta khas lindung wanita daripada gangguan seksual. Utusan Malaysia, 23 Februari: 3.

O’Connell, C.E. dan Korabi, K. (2000). Sexual harassment: The Relationship of personal vulnerability work context, perpetrators status, and types of harassment of outcomes, Journal of Vocational Behaviour, 58(3),299-

Persekutuan Majikan Malaysia. (2009). Kod Amalan Untuk Mencegah Dan Membasmi Gangguan Seksual DI tempat Kerja. Malaysia; Malaysian Employers Federation (MEF). 
Pope, K.S., Levenson, H. Dan Schover, L.R. (2001). Sexual intimacy in psychology traning: Results and implications of a national survey. America Psychologist, 34, 682-689.

Prentice, D.A. dan Carvanza, E. (2002). What women and men should be, shouldn't be, are allowed to be, and don't have to be: The contents of prescriptive gender stereotypes. Psychology of Women Quarterly, 26, 269-

Rayburn, C.A. (1986). Women and stress, some implication for therapy: The dynamics of feminist therapy. Women and Therapy, 5, 230-247.

Rubin, J.L. dan Borgers,S.B. (2004). Sexual harassment in Universities During the 1980's. Sex Roles, 23, 397-411.

Renzetti, C.M. dan Curan, D.J. (1999). Women, Men and Society (4th ed). Boston: Allyn \& Bacon.

Roethleiner, C. (1995). Untersuchung zur sexuellen Belastigung von Frauen am Arbeits-platz und ihre Auswirkungen, unter Berucksichtigung der Arbeitszufriedenheit, Diplom Arbeit, Salzburg Universitat. (dlm European Commision, Directorate-General for Employment, Industrial Relations and Social Affairs, Unit V/D.5 Manuscript Completed 1998).

Rohani Abdul Rahin (2004a). Kefahaman Teoritikal dan Implikasi Perundangan Dalam Fenomena Gangguan Seksual, Paper presented at $5^{\text {th }}$ National Conference of the Southeast Asian Association for Gender Studies-Rethingking Gender and Human Development: Security for the future, organized by Faculty of Law Publication Committee and Research Development and Planning Committee, UKM-Bangi.

Rohani Abdul Rahim (2005). Sexual harassment of women clerical workers in the workplace. Thesis Doktor Falsahah (tidak diterbitkan). Universiti Putra Malaysia-Serdang Sabitha, M. 2002. Sikap Terhadap Wanita dan Kesannya Keatas Persepsi Gangguan Seksual di Tempat Kerja. Jurnal Psikologi Malaysia,16, 101-104.

Sabitha, M. (2002). Sikap Terhadap Wanita dan Kesannya Keatas Persepsi Gangguan Seksual di Tempat Kerja. Jurnal Psikologi Malaysia,16, 101-104.

Sabitha, M. (2003). Persepsi Gangguan Seksual di Institusi Pendidikan: Kejadian dan Strategi Penyelesaian. Kertas kerja yang dibentangkan di Seminar Kebangsaan Penyelidikan Pendidikan Guru: Pembangunan Perguruan kearah Pendidikan Berkualiti. Anjuran Maktab Perguruan Bayu Lintang, Kucing Sarawak, 19-20.

Salisbury, J., Ginorio, A. B., Remick, H. \& Stringer, D.M. (1986). Counseling victims of sexual harassment, Psychoterapy, 23, 316-324.

Schneider, B.E. 1991. Put up and shut u. Workplace sexual harassment, Gender and Society, 5(4), 533-546.

Schultz, V. (1998). Reconceptualizing sexual harassment, Yale Law Jornal, 107(6), 16831805.

Schultz, D. dan Schultz, S.E. (2010). Psychology and Work Today, Edisi ke-10. Publisher: Pearson.

Silverman, D. (1996). Sexual harassment working women a dillema. Quest: A Feminist Quaterly, 3(3), 15-24.

Singer,D.M. (2003). Impact of sexual harassment in the workplace. Sex Roles, 16, 111-124.

Tangri, S.S., Burt, M.R. \& Johnson, L.B. (1982). "Sexual harassment at work: Three explanatory models", Journal of Social Issues, 38(4), 33-54. 
Tangri, S. dan Hayes, S.M. (1997). Theories of sexual harassment. Dalam W. O. Donohue (Ed.), Sexual harassment: Theory, research, and treatment, 99-111. Needham heights, MA: Allyn dan Bacon.

Terpstra, D.E. \& Cooks, S.E. (1985). Complainant Characteristics and Reported Behaviors and Consequences with Formal Sexual Harassment Charges. Personnel Journal. 38, 559574.

U.S. Merit Protection Board. (2004). Sexual Harassment in The Federal Government: An Update Washinghton D.C. : U.S. Government Printing Office.

Welsh, S. (1999). Gender and sexual harassment. Annual Review of Sosiology, 25, 169-190.

Yahaya Mahamood dan Zulaiha Mohamad Besar. 2002. Gangguan Seksual: Satu Kajian Psiko Kesihatan di Kalangan Pekerja Kolar Biru Wanita di Sebuah Bandar. Jurnal Psikologi Malaysia. 16,14-23.

Yahaya A. Azizi, Hasmadi. (2002). Masalah gangguan seksual di kalangan guru-guru di Johor, Melaka, Negeri Sembilan dan Selangor. 2010. Conference dan Workshop. Universiti Teknologi Malaysia Institutional Repository. UTM - Malaysia.

Zaiton Nasir. (1998). Ancaman Seks di Pejabat. Dewan Masyarakat. 7, 38.

Zalk, S.R. (1990). Men in the academy: A psychological profile of harassment. Dalam M. Paludi (Ed.), Ivory power : Seual harassment on campus, 141-175. Albany: State University of New York Press.

Zinitulniza Abdul Kadir. (2003). Punca masalah gangguan seksual. Harian Metro, 22 September: 20. 